\begin{tabular}{lc}
\hline CURRENT & ISSN: 0973-4929, Vol. 15, No. (1) 2020, Pg. 68-74 \\
WORLD & Current World Environment
\end{tabular}

ENVIRONMENT WWW.cwejournal.org

\title{
Environmental Perspective of Stone Crushing and Quarrying: A Case Study from Poonch District of Jammu and Kashmir, India
}

\begin{abstract}
JAVED MANZOOR $^{1 *}$ and MAHROOF KHAN ${ }^{2}$
${ }^{1}$ Department of Environmental Science, Government Degree College Mendhar, Jammu Kashmir, India. ${ }^{2}$ Department of Botany, Government Degree College Mendhar, Jammu Kashmir, India.
\end{abstract}

\begin{abstract}
Stone crushing and quarrying activities have considerable effects on environmental quality and human health. Present study was conducted to assess environmental perspectives of various stone crushing and quarrying units functioning in Poonch district of Jammu and Kashmir, India. Present study was based on field work, general observations, questionnaire and laboratory experimentation. Serious consequences in term of huge dust, noise and water pollution, decrease in agricultural productivity, loss of local biodiversity, land degradation, generation of unproductive wastelands, deterioration in water quality, accidents, socioeconomic conflicts and severe health hazards to the people residing near these units are observed. No effort is made by the local management of these units functioning in the area to minimize negative impacts on environment and human health. Present study imitates that regulatory measures are urgently required to protect the environment and human health against different types of pollutions caused by these units.
\end{abstract}

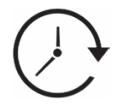

Article History

Received: 10 February 2020 Accepted: 23 March 2020

\section{Keywords}

Crushing;

Dust;

Effects;

Environment;

Water;

Quarrying.

\section{Introduction}

To meet the increasing demand of the population, massive exploitation of environmental resources has taken place in the recent times and is ongoing every day. Threats to environment from the progressive deterioration of the biosphere have emerged as one of the primary issues of the recent times.
Various human induced activities have direct and indirect impacts on the environment. Stone crushing and quarrying is one of such activity. Though socioeconomically stone crushing and quarrying is an important industrial sector engaged in the production of crushed stones used as raw material for various constructional purposes but at the same

CONTACT Javed Manzoor Javedevs @ gmail.com Department of Environmental Science, Government Degree College Mendhar, Jammu Kashmir, India.

\section{(c) (i)}

(c) 2020 The Author(s). Published by Enviro Research Publishers.

This is an Open Access article licensed under a Creative Commons license: Attribution 4.0 International (CC-BY).

Doi: http://dx.doi.org/10.12944/CWE.15.1.10 
time it has become the cause of concern everywhere in the world. ${ }^{1}$ Like many other man-made activities it also cause significant impact on the environment as it produce various types of pollutions such as noise pollution, water pollution, dust and air pollution beside effecting natural vegetation, soil, forests and natural habitat of wildlife. ${ }^{2}$ Noise produced by stone crushing and quarrying activities constitute a severe form of pollution which has significant effect on human being. As per WHO, It is the third most hazardous pollution after air and water. Noise produced in a stone crushing and quarrying industry is regarded as one of the primary annoyance for human beings as it produces direct and cumulative adverse impacts causing hearing loss, stress, cardiovascular diseases, high blood pressure, insomnia and depression etc. Stone dust is a primary aerosol and it contributes as a major source to air pollution and its severity depends upon several factors pertaining to the local area and local microclimatic conditions. It has detrimental effects on people and environment including flora and fauna, change in soil $\mathrm{pH}$, results in the formation of haze thereby reducing visibility in surrounding areas. Stone crushing generates huge amount of dust of various sizes, which passes into air and disperse considerable amount of suspended particulate matter and gaseous pollutants into air. Dust not only settles on plants and vegetation but has also physical effects on plants such as blocking and damaging their internal structures, abrasion of leaves and cuticles thereby resulting in lowering of agricultural yield. Exposure to dust may produce several diseases including silicosis. Dust not only act as a nuisance but also have possible ill effects on the health of the population residing nearby and on the surrounding environment, biodiversity, vegetation and water bodies etc. ${ }^{3,4}$ Exposure to dust may result in repiratory disordes and diseases like silicosis in addition to skin infections.

In addition to dust and noise, stone crushing and quarrying activities also modify the existing ecosystems thereby disturbing local hydrological and geological regimes. ${ }^{4}$ These activities also modify the substratum, landscape patterns, destruct natural habitat, disrupt natural succession as well as change genetic resources. ${ }^{6}$ Dumping of waste rocks in open areas near the crushing and quarrying sites often disrupts natural drainage and cause diversion of rivers and streams into farming areas resulting in the floods. Moreover due to increased stone crushing and quarrying activities, various social challenges and conflicts were also reported in many parts of the world which include issues of land use, socio-cultural survival and displacement of communities, damage to cultural sites, self-determination, resource control and the formation of ghost towns. ${ }^{7}$ Poonch is one of the remotest districts of Jammu and Kashmir, India and is swiftly moving toward urbanization. In the present study an attempt is made to assess environmental impacts of stone crushing and quarrying units functioning in the area.

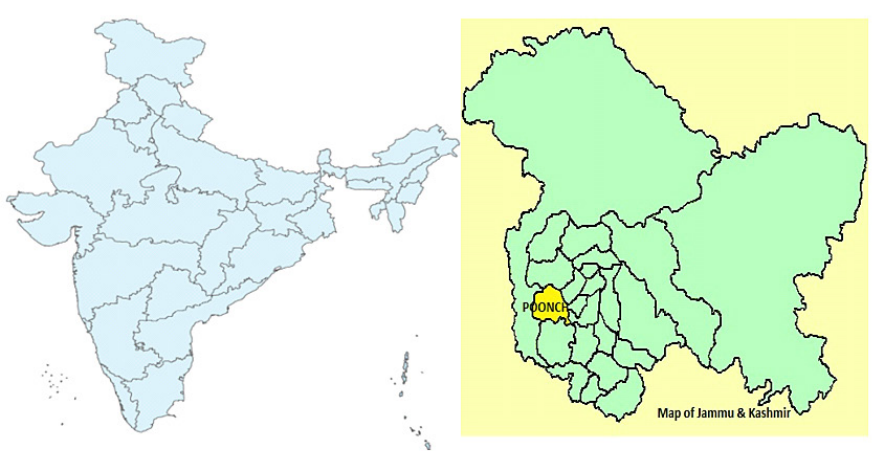

India

Jammu and Kashmir

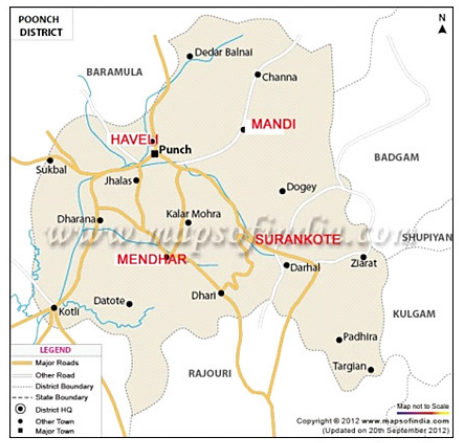

Poonch District

\section{Maps of study area}

\section{Material And Methods \\ Study area}

The present study is conducted in Mendhar subdivision of Poonch district of Jammu and Kashmir,
India. Poonch district lies in the foothills of Pir Panjal range in the western Himalayas and is geographically located $33^{\circ} 25^{\prime}$ to $34^{\circ} 01^{\prime}$ north latitude and $73^{\circ} 58^{\prime}$ to 74 은 ${ }^{\prime}$ east longitudes with an average elevation 
of 981 meters above the sea level. Climate of the study area ranges from sub tropical to temperate with a temperature scope of $19-34^{\circ} \mathrm{C}$ in summer to $6-17^{\circ} \mathrm{C}$ in winter. Study area is drained by Mendhar river and Salgad nallah besides some other small rivulets.

\section{Methodology}

This study is based on both primary and secondary sources. Primary sources include field survey, general observations, questionnaire, interviews and laboratory experimentation. Secondary sources include books and journals. Field survey and general observations were made to assess the effects of dust pollution on environment, local flora and on agricultural crops. Dust load estimation was also done to assess the impact of dust on some plants growing near these units. ${ }^{8} 20$ leaves from different branches of each selected plant species were collected and kept in separate polythene bags. The leaves were brought to laboratory and washed separately for each plant species. The water containing dust then filtered through pre-weighed filter paper. The filter papers were dried overnight in the oven and weighed again. The difference in the weight of filter paper yields the amount of dust on sampled leaves. The leaves surface area was calculated. From this data, dust weight per $\mathrm{cm}^{2}$ of leaf was calculated. For assessing the effects of dust and noise pollution on workers and local residents residing near these units questionnaire method was used. 240 respondents were chosen randomly and interviews were conducted. Respondents include local residents, housewives, workers, employees and students. Two separate questionnaires with variables pertaining to various aspects of dust and noise pollution were prepared. Respondents were asked questions, their answers were recorded and finally the percentage was calculated. Intensity of noise produced by stone crushing and quarrying units is measured with the help of Mini sound level meter Model no. METRAVI SL-4010 with weighting frequency of $A$ and $C$. Noise level was measured in each crushing units under study during the working hours between 6: am to 8:00 pm. To measure the extent of sound, sound level meter was turned on to fast response point. Weighting scale with frequency " $A$ " was used. Sound level was measured at every 5 meters from the crushing points and the measured values were recorded as the sound level of the corresponding area at a distinct period. For assessing the effects of stone crushing and quarrying on the water bodies general observations were made. The water quality of two major bodies i,e Mendhar river and Salgad nallah water is assesed by conducting physico-chemical analysis.

\section{Results and Discussion General Observations}

To assess various environmental impacts of stone crushing and quarrying units functioning in the study area an extensive field survey was undertaken from April 2019 to September 2019 and it was observed that.

- Most of the stone crushing units functioning in the area are located on the bank of Mendhar river and Salgad nallah.

- $\quad$ None of the stone crushing units in the area is provided with wind breaking walls and green belts.

- None of the stone crushing units functioning in the area has installed proper water sprinkling and dust containment system for dust suppression.

- Huge clouds of dust are noticed all over the area which remained suspended in the air even after the operation is off.

- River beds and flood plains are heavily exploited by the crushing units for the quarrying of stones needed for their operation.

- About 12 villages with a population of about 16,764 people are directly exposed to different types of pollutions produced due to the functioning of these units.

\section{Environmental Perspective Dust and Its Impacts}

It was observed that large scale dust is produced in and around the stone crushing and quarrying units functioning in the area from unloading of raw material to open stocking of crushed products of different sizes. During field survey it was observed that dust is directly affecting local flora/vegetation and agriculture as large scale dust is observed in the surrounding atmosphere, on vegetation, on agricultural crops and grasslands. The plants growing around these stone crushing units within the radius of $50-500$ meters was observed and dust load estimation was done for some selected plant species growing in the vicinity of only one of the unit because of similar vegetation and topographic features of the study 
area (Table 1.). During investigation maximum dust was found on almost all the plant species sampled. Visible symptoms like chlorosis, necrosis, retarded/ stunted growth and various modifications were noticed in plants and agricultural crops. ${ }^{9,10}$ Farmers in the study area reported a drastic decrease in the yield of agricultural crops due to deposition of large scale dust and other particulate matter on crops and surrounding areas.

\section{Table 1: Dust load estimation on leaves of selected plant species within a radius of 50-500 meters in the vicinity of one of the stone crushing unit functioning in the area}

\begin{tabular}{lllll}
\hline S. No & $\begin{array}{l}\text { Name of the } \\
\text { Plant species }\end{array}$ & $\begin{array}{l}\text { Dust load on } \\
\text { 20 leaves } \mathbf{( m g )}\end{array}$ & $\begin{array}{l}\text { Dust load per } \\
\text { leaf }(\mathbf{m g})\end{array}$ & $\begin{array}{l}\text { Dust load } \\
\mathbf{m g} / \mathbf{c m}^{2}\end{array}$ \\
\hline 1 & Quercus oblongata & 720 & 36 & 0.72 \\
2 & Acacia nilotica & 240 & 12 & 0.21 \\
3 & Morus alba & 680 & 34 & 0.56 \\
4 & Melia azadarach & 1040 & 52 & 0.86 \\
5 & Zizyphus mauritiana & 580 & 29 & 0.72 \\
6 & Grewia optiva & 1198 & 59.9 & 1.08 \\
7 & Ficus palmata & 980 & 49 & 1.06 \\
8 & Punica granatum & 265 & 13.25 & 0.33 \\
9 & Elaegnus parvifolia & 220 & 11 & 0.27 \\
10 & Cryptolepis dubia & 395 & 19.75 & 0.54 \\
\hline
\end{tabular}

Due to open stock pilings, whenever wind blows considerable amount of fine dust get suspended in the air adding to reduced visibility and the problems of air pollution. Even during non-operation of these crushing units substantial amount of dust emissions are also observed in the stone crushers cluster area. $^{11}$

During interaction with the residents regarding the effects of dust on health it is revealed that $70 \%$ of the residents have knowledge about dust as pollution, $64 \%$ of the respondents stated that it effects health, $49 \%$ stated that it causes skin infections like rough and dry skin, $53 \%$ stated that it causes respiratory diseases like asthma, inflammation, cold, cough, allergies, throat and chest infection etc. Only $10 \%$ of the respondents have knowledge that stone crushing dust may also results in silicosis.

Stone quarrying and its effects on water resources During the study it was observed that stone crushing units located in the area are heavily exploiting the river beds and flood plains of Mendhar river and Salgad nallah for stones due to which massive transformation and diversion of the water bodies occurred at many places. Flooding and inundation of agricultural field during rainy season has become a regular phenomenon. It is also observed that unplanned stone quarrying from the river beds is deteriorating the quality of water in the area. Physicochemical parameters of water within one kilometre of Mendhar river and Salgad nallah are analyzed by following the standard method..$^{12}$ Analysis of water revealed that maximum of the parameters for water quality are found to be above the acceptable limit for water quality standards as prescribed by WHO and BIS, (Table 2.) which indicates that the water is unfit for human and domestic consumption. Both the water bodies in the area of these units are also found to be devoid of aquatic flora and fauna.

Furthermore, unplanned stone quarrying operations in the river beds has disrupted the existing movement of surface and groundwater and also interrupted natural water recharge leading to reduced availability of drinking water for the residents and particularly for wildlife near and downstream from the quarrying sites. Moreover a number of abandoned excavated sites adjoining Mendhar river and Salgad nallah are also noticed in the area. 
Table 2: Physico-chemical characteristics of water of Mendhar river and Salgad nallah within one kilometre of study area

\begin{tabular}{llll}
\hline Parameters & $\begin{array}{l}\text { Mendhar river } \\
\text { (Average values) }\end{array}$ & $\begin{array}{l}\text { Salgad nallah } \\
\text { (Average values) }\end{array}$ & $\begin{array}{l}\text { WHO } \\
\text { (Average values) }\end{array}$ \\
\hline Temperature & $22.3^{\circ} \mathrm{C}$ & $24.1^{\circ} \mathrm{C}$ & -- \\
$\mathrm{pH}$ & 9.26 & 8.93 & $6.5-8.5$ \\
Turbidity & $34.6 \mathrm{NTU}$ & $36.1 \mathrm{NTU}$ & $5-10 \mathrm{NTU}$ \\
Total dissolved solids & $745 \mathrm{mg} / \mathrm{l}$ & $791 \mathrm{mg} / \mathrm{l}$ & $500 \mathrm{mg} / \mathrm{l}$ \\
Dissolved oxygen & $1.92 \mathrm{mg} / \mathrm{l}$ & $2.12 \mathrm{mg} / \mathrm{l}$ & $>6 \mathrm{mg} / \mathrm{l}$ \\
Total hardness & $215 \mathrm{mg} / \mathrm{l}$ & $264 \mathrm{mg} / \mathrm{l}$ & $300 \mathrm{mg} / \mathrm{l}$ \\
Biological Oxygen Demand & $4.35 \mathrm{mg} / \mathrm{l}$ & $3.96 \mathrm{mg} / \mathrm{l}$ & $4-6 \mathrm{mg} / \mathrm{l}$ \\
Fluoride & $1.62 \mathrm{mg} / \mathrm{l}$ & $1.54 \mathrm{mg} / \mathrm{l}$ & $1-1.5 \mathrm{mg} / \mathrm{l}$ \\
Total Alkalinity & $267.3 \mathrm{mg} / \mathrm{l}$ & $321 \mathrm{mg} / \mathrm{l}$ & $200 \mathrm{mg} / \mathrm{l}$ \\
\hline
\end{tabular}

Noise and .ts Impacts

It was noticed that almost all the stone crushing and quarrying units are situated at a distance of just 100-200 meters away from residential areas therefore people are directly exposed to noise pollution. Intensity of noise produced in all the five stone crushing and quarrying units under study was recorded at quarrying points, crushing points, during vehicular movement to and fro from these units and within the villages nearby and the average values were calculated. Maximum noise level is recorded at M/S S.K.stone crushing and quarrying unit at different points with an average value of $87.4 \mathrm{~dB}(\mathrm{~A})$ at quarrying points, $104 \mathrm{~dB}(\mathrm{~A})$ during crushing and $108 \mathrm{~dB}(\mathrm{~A})$ during vehicular movements while minimum noise level is recorded at M/S Al-hilal stone crushing unit (Table 3 ). It is found that the level of noise produced and recorded during the operation of these units is higher than the ambient air quality standards in respect of noise as per the Noise Pollution (Regulation and Control) Rules, 2000 (Table 4.). Due to pervasive, irritating and loud noise, mostly the housewives, old aged persons, children and students suffers a lot and have developed certain physical, physiological and psychological disturbances. ${ }^{13}$

Table 3: Measurement of Noise level at different points during the operation of different stone crushing units in the study area

\begin{tabular}{lllll}
\hline \multicolumn{5}{c}{ Measurement of Noise level in dB (A) } \\
\hline $\begin{array}{llll}\text { Crushing } \\
\text { Units }\end{array}$ & $\begin{array}{l}\text { During } \\
\text { quarrying } \\
\text { (Average value) }\end{array}$ & $\begin{array}{l}\text { During } \\
\text { crushing } \\
\text { (Average value) }\end{array}$ & $\begin{array}{l}\text { During } \\
\text { Vehicular } \\
\text { movement } \\
\text { (Average value) }\end{array}$ & $\begin{array}{l}\text { Within the } \\
\text { villages nearby } \\
\text { (Averagevalue) }\end{array}$ \\
\hline M/S National Stone crusher & 78 & & 102 & 88 \\
M/S S.K stone crusher & 87.4 & 96.8 & 108 & 92 \\
M/S Himalayan stone crusher & 81.2 & 104 & 94 & 86 \\
M/S Al-Hilal stone crusher & 76.7 & 101 & 84 & 79 \\
M/S R.B. Stone crusher & 78.8 & 95.2 & 89 & 87.4 \\
\hline
\end{tabular}

During interaction $28 \%$ of the respondents reported that noise produced by stone crushing and quarrying units results in mental tension, 44\% respondents reported that it results in anxiety, $80 \%$ stated that it causes headache, $76 \%$ stated that it results in irritation, $28 \%$ reported that it results in high blood 
pressure,74\% reported that it causes insomnia, $53 \%$ reported that it is resulting in stress and discomfort, $49 \%$ reported that it results in hearing impairment, $10 \%$ reported that it results in tinnitus, $10 \%$ reported that causes emotional disturbances. $94 \%$ of the respondents reported that continue loud and annoying noise effects the studies.

Table 4: Ambient Air Quality standard for Noise

\begin{tabular}{llll}
\hline & S. No & Category of area/zone & \multicolumn{2}{l}{ Limits in $\mathbf{d B}(\mathbf{A})$ Leq } \\
\cline { 3 - 4 } & & Day time & Night time \\
\hline A & Industrial Area & 75 & 70 \\
B & Commercial Area & 65 & 55 \\
C & Residential area & 55 & 45 \\
D & Silence zone & 50 & 40 \\
\hline
\end{tabular}

Source: The Noise Pollution (Regulation and Control) Rules, 2000

In addition to this, various social conflicts have also got surfaced in the area over sharing of water, soil and other local minor minerals resources. The land near the river beds and adjoining area once used by the locals for grazing of their cattle has got transformed into dumping ground for the left out materials by these stone crushing and quarrying units.

\section{Conclusion}

From the present study it is revealed that stone crushing and quarrying units functioning in the area have direct negative impacts on natural vegetation, soil, agriculture, water bodies, aquatic life,workers and the other local residents nearby. No efforts on the part of management of the crushing and quarrying units are made to minimize pollution and its impacts on environment and human health.

\section{Recommendations}

Keeping in view the present study, the following recommendations are made.

- $\quad$ Stone crushing and quarrying units operating in the area must install proper dust containment and water sprinkling system at different dust emitting points to arrest the escaping dust.

- Boundary wall must be provided and green belt along the boundary wall must be developed by the stone crushing units

- Suitable water conservation measures to preserve and enhance ground water resources must be implemented and the quarrying activity must be restricted well above the static water table so as to ensure that the ground water may not get impacted.

- $\quad$ The stone crushing and quarrying units must adopt some protective measures to minimize the adverse impacts of noise, dust and other types of pollution on local residents.

- $\quad$ The excavated area must be properly filled to avoid the contamination of surface water resources and the effects on the aquatic biota.

- There must be the sustainable utilization of the natural resources.

\section{Acknowledgement}

Authors are highly thankful to Principal, Government Degree College Mendhar and the Department of Environmental Science, Government Degree College Mendhar for providing necessary facilities and help during the study.

\section{Funding}

The author(s) received no financial support for the research, authorship, and/or publication of this article.

\section{Conflict of Interest}

Authors declare that there is no conflict of interest in publishing this case study. 


\section{References}

1. Central Pollution Control Board, Comprehensive Industry Document, Stone Crushers, Central Pollution Control Board, Parivesh Bhawan, East Arjun Nagar, Shahdara,Delhi- 110032, February 2009.

2. Chaurasia Sadhana, Singh Ravinder, Pathak Vandna. Environmental Study of Stone Crusher, Indian Journal of Environmental Protection. 2009; 29 (7): 653-656.

3. Ramana T.V. Management of stone crushing industry and its impact on Employees and environment "a case study". International journal of Research in Commerce, Economics and Management. 2011; 1 (3):154-157.

4. Amitshreeya R and Panda R.B. Dust pollution in stone crusher units in and Balasore, Orissa, India. Journal of industrial Pollution Control. 2012; 28(1):41-44.

5. Panda A.K.S, Murlidhar J, Shahoo B.N. Seasonal water quality assessment of Jajong iron and mining area. Journal of Industrial pollution control. 1996; 12(1): 9-14.

6. Ukpong E.C. Environmental and Social Impacts of Stone Quarrying-A case study of Kolhapur district, International Journal of Current Research.2014; 6(3): 5664-5669.

7. Nasserdine K, Mimi Z, Bevan B, Elian B. Environmental management of the stone cutting industry. Journal of Environmental
Management. 2009; 90:466-470.

8. Chang Y.M, Chang T.C, Chen W.K. An estimation on overall emission rate of fugitive dust emitted from road construction. Environmental Engineering Science.1999; 16:253-267.

9. Kumar Pawan. The mining activity and its impact on plant biodiversity: A case study at Bhiwani Open Cast mining zones-Haryana, India. Asian journal of Plant Sciences and Research. 2013; 3(6):78-83.

10. Saha Dulal Chandra, Pratap Kumar Padhy. Effects of stone crushing industry on Shorea robusta and Madhuca indica foliage in Lalpahari forest. Atmospheric Pollution Research. 2011; 2(4):463-476.

11. Agarwal SP. Impact of dust pollution. Indian Journal of Environment Protection. 1994; 14(5):334-335.

12. APHA. Standard Methods for Examination of Water and Wastewater, 20th Edition, American Public Health Association, Washington D. C. 1985.

13. Paramesha D, Naik Ushamalini, Somashekar R. K. Noise Pollution in Stone Quarrying Industry - A Case Study in Bangalore District, Karnataka. Indian Journal of Industrial Pollution Control. 2007; 23(1):43-48. 